\title{
Characteristics of Static and Dynamic Postural Balance of Elderly Persons Wearing an Abdominal Belt
}

$\begin{array}{lllll}\text { 松田 雅弘 }{ }^{1)} & \text { 塩田 琴美1) } & \text { 高梨 } & \text { 晃 }{ }^{1)} & \text { 野北 好春1) } \\ \text { 川田 教平 }{ }^{1)} & \text { 宮島 恵樹1) } & \text { 細田 昌孝1) } & \text { 渡邊 } & \text { 修 }\end{array}$

TADAmitsu MATSUDA ${ }^{1)}$, KOtOMi SHIOTA ${ }^{1)}$, AKIRA TAKANASHI ${ }^{1)}$, YoshiHARU NOGITA ${ }^{1)}$, KYOUHEI KAWADA $^{1)}$, SHIGEKi MIYAJIMA ${ }^{1)}$, MASATAKA HOSODA ${ }^{1)}$, SHU WATANABE ${ }^{2)}$

1) Department of Physical Therapy, Faculty of Health Science, Ryotokuji University: 5-8-1 Akemi, Urayasu, Chiba 279-8567, Japan. TEL +81 47-382-2598

2) Graduate School of Human Health Sciences, Tokyo Metropolitan University

Rigakuryoho Kagaku 24(4): 489-492, 2009. Submitted Oct. 31, 2008. Accepted Feb. 25, 2009.

ABSTRACT: [Purpose] We assessed whether abdominal belts can facilitate static and dynamic postural balance in the elderly. [Subjects] The subjects were fourteen healthy elderly persons (mean age $70.0 \pm 6.8$ yrs) with no significant medical history of neurological or orthopedic disease. [Methods] Performance of static and dynamic postural standing balance with or without an abdominal belt was measured using a Gravicorder G-620 stabilometer (Anima Co.). [Results] No significant difference was found in static balance between the two conditions, whereas a significant difference was observed in dynamic balance. [Conclusion] These results suggest that wearing an abdominal belt causes higher abdominal pressure and improved dynamic postural balance due to adjusted postural tone.

Key words: abdominal belt, abdominal pressure, standing balance

要旨：[目的］簡易的な腹部ベルトを使用し, 重心動摇計を用いて健常高齢者の静的と動的立位バランスを明らか にすることを目的とした。[対象］神経学的・下肢に整形外科的な既往のない健常高齢者 14 名（平均年齢 $70.0 \pm 6.8$ 歳）とした。[方法］腰痛用ベルト有り姿勢とベルトなしの立位姿勢で, 重心動摇計を用いて静的と動的バランス を測定した。[結果］両群間に静的バランスで有意差は認められなかったが，動的バランスではベルトなし姿勢よ りもベルト有り姿勢において重心の移動範囲が有意に大きかった。[結語］腹部ベルトで腹圧を高めることにより 全身の姿勢筋緊張が整い，動的なバランスが向上したと考えられた。

キーワード：腰痛ベルト, 腹圧, 立位バランス

1) 了德寺大学 健康科学部理学療法学科：千葉県浦安市明海5-8-1（†279-8567） TEL 047-382-2598

2) 首都大学東京 人間健康科学研究科

受付日 2008年10月31日 受理日 2009年2月25日 


\section{I. はじめに}

日本は世界最長寿国の一国であり，高齢化率は徐々 に上昇し 2020 年には $26.9 \%$ となり, 4 人に 1 人以上が 65 歳以上の高齢者になると考えられている1)。高齢者が 要支援, 要介護状態に至る要因として “転倒・骨折”が 上位を占めており，この要因によって年間約 32 万人の 高齢者が要介護状態に至っていると推定されている。 近年, 高齢者の転倒による大腿骨頸部骨折が, 高齢者 のADL 能力やQOLを下げることの一要因になると報告 されている2)。そこで理学療法士らは転倒を予防する ために, 高齢者に対して定期的な運動やバランス練習 などを取り入れている。しかし，今後更なる高齢化社 会が到来すると, 十分な運動療法を受けることができ ない高齢者が増加することが考えられる。そこで, 簡 易的なベルトによりバランス機能の向上と転倒が予防 できれば, 転倒件数の減少や高齢者の ADL 能力と QOL の維持につながるのではないかと考えられる。

転倒とバランス機能との関連性を示寸多数の報告3,4) があり, 転倒予防にはバランス機能の改善が一つの指 標となっている。バランス機能の改善には様々な要因 が考えられている。特に, 中高齢者の腹筋群に注目し た報告では, 8 週間という短期間の腹筋群単独強化によ り腹筋力の向上と身体機能, とりわけバランス機能の 改善がみられたことが報告されている5)。この報告で は, 腹筋群の強化により適度な腹腔内圧が確保され, それに伴い胸郭及び腹部の固定性が高まり, 体幹の安 定性が向上したことがバランス機能改善の一因として 考察付けられている。

体幹の安定性に寄与寸る筋に, ローカル筋群（腹横 筋，多裂筋など）があげられる。このローカル筋群は 身体の深部に位置する比較的小さな筋群で主に姿勢制 御に関係している。なかでも腹横筋は体幹の最深部に 位置する筋で体幹の安定性に重要な役割がある。Urquhart $ら^{6,7)}$ の報告で, 腹横筋は胸郭の固定, つまり体幹をコ ルセットのように締め付けることで体幹の安定性に役 立っているとされている。

腹部ベルトは腹圧を高めることで, 脊柱と体幹の安 定性を高め, 腰椎の負担を軽減させている。そのため, この腹部ベルトを利用して腹横筋の代わりに体幹の安 定性を向上させれば，バランス能力が向上することが 推察される。

そこで本研究では, 腹部の圧力を高め, 腰部の脊椎 安定性を高めるために簡易的な腹部ベルトを使用し, 健常高齢者の立位バランスがどのように変化するかに
注目した。重心動摇計を用いて, 自然立位時の変化を 調べる静的バランスと自発的に重心を制御する動的バ ランスの違いを明らかにすることで，腹部ベルトの効 果の検討を目的に実施した。

\section{II. 対象と方法}

\section{1. 対象}

対象は, 神経学的・下肢に整形外科的な既往のない 健常高齢者 14 名（61-84 歳，平均年齢 $70.0 \pm 6.8$ 歳 ; 男 性 5 名，女性 9名）とした。平均身長 $158.1 \pm 5.9 \mathrm{~cm}$, 平 均体重 $51.5 \pm 7.8 \mathrm{~kg}$ であった。なお, 全対象者に対して, 事前に本研究の目的と方法を説明し, 研究協力の同意 を得た。

\section{2. 方法}

測定姿勢は, 腹部に何も巻かない通常の立位姿勢(ベ ルトなし姿勢）と対象の腹囲に合った最大幅 $23 \mathrm{~cm}$, 最 小幅 $15 \mathrm{~cm}$ の腹部ベルト (MAXBELT me3; 日本シグマッ クス）を巻いた立位姿勢（ベルト有り姿勢）の2通りの 立位姿勢を選択した。腹部ベルトを被験者の主観とし て少しきついと感じる圧力で腸骨稜をベルトの中間と し，ベルトを止める部分を腹部中央としてベルトを巻 いた。

ベルトなし姿勢とベルト有り姿勢の 2 種類の姿勢で, 重心動摇計（アニマ社製 G-620）で静的バランス（静 止立位）と動的バランス（前後・左右に最大重心移動） を測定した。静的バランスのサンプリング周期は $20 \mathrm{~Hz}$, サンプリング時間は開眼／閉眼各30秒間とした。対象 者には，フォースプレート上のマーキング位置に合わ せて足先を各 $15^{\circ}$ 外側に向けた閉脚立位をとらせた。一 方, 動的バランスは開眼にてサンプリング周期 $100 \mathrm{~Hz}$, サンプリング時間は 60 秒間とした。動的バランスの測 定時は, 前後左右に各方向とも両側足底面を離床させ ず接地位置を動かさない範囲で最大限の重心移動を要 求し, 各方向で 10 秒間一旦停止することを求めた。測 定は自然な肩幅に近い両踵間を $20 \mathrm{~cm}$ 離し足先を各 $15^{\circ}$ 外側に向けるように設定した。両バランス測定とも, フォースプレート上の対象者の踵の位置より $2 \mathrm{~m}$ 前方 の正中位で対象者の目の高さに合わせた固視点を設置 して, 対象者に注視を求めた。

静的バランスと動的バランスの間には十分な休息を とらせ, ベルトなし姿勢とベルト有り姿勢の順番はラ ンダムとし, ベルトなし姿勢とベルト有り姿勢のクロ スオーバーの研究デザインを用いた。 
表 1 静的バランスにおける条件間比較 $(\mathrm{n}=14)$

\begin{tabular}{lccc}
\hline & ベルトなし姿勢 & ベルト有り姿勢 & 有意性 \\
\hline 開眼 & & & \\
総軌跡長 $(\mathrm{cm})$ & $45.63 \pm 17.59$ & $47.76 \pm 14.47$ & N.S. \\
矩形面積 $\left(\mathrm{cm}^{2}\right)$ & $5.83 \pm 3.56$ & $5.96 \pm 3.45$ & N.S. \\
外周面積 $\left(\mathrm{cm}^{2}\right)$ & $2.04 \pm 1.10$ & $2.29 \pm 1.32$ & N.S. \\
実効值面積 $\left(\mathrm{cm}^{2}\right)$ & $1.34 \pm 0.78$ & $1.45 \pm 0.80$ & N.S. \\
$\mathrm{X}$ 方向最大振幅 $(\mathrm{cm})$ & $2.23 \pm 0.70$ & $2.43 \pm 0.75$ & N.S. \\
$\mathrm{Y}$ 方向最大振幅 $(\mathrm{cm})$ & $2.41 \pm 0.80$ & $2.30 \pm 0.62$ & N.S. \\
閉眼 & & & \\
総軌跡長 $\left(\mathrm{cm}^{2}\right)$ & $62.60 \pm 28.44$ & $59.06 \pm 29.48$ & N.S. \\
矩形面積 $\left(\mathrm{cm}^{2}\right)$ & $7.81 \pm 3.55$ & $7.41 \pm 3.99$ & N.S. \\
外周面積 $\left(\mathrm{cm}^{2}\right)$ & $2.94 \pm 1.38$ & $2.89 \pm 1.57$ & N.S. \\
実効值面積 $\left(\mathrm{cm}^{2}\right)$ & $1.86 \pm 0.86$ & $1.96 \pm 1.13$ & N.S. \\
X 方向最大振幅 $(\mathrm{cm})$ & $2.50 \pm 0.69$ & $2.34 \pm 0.59$ & N.S. \\
Y 方向最大振幅 $(\mathrm{cm})$ & $2.98 \pm 0.76$ & $3.00 \pm 1.15$ & N.S. \\
\hline
\end{tabular}

平均值士標準偏差, N.S. : not significant

表 2 動的バランスにおける条件間比較 $(\mathrm{n}=14)$

\begin{tabular}{lccc}
\hline & ベルトなし姿勢 & ベルト有り姿勢 & 有意性 \\
\hline 矩形面積 $\left(\mathrm{cm}^{2}\right)$ & $224.59 \pm 87.12$ & $253.03 \pm 81.85$ & $\mathrm{p}<0.05$ \\
外周面積 $\left(\mathrm{cm}^{2}\right)$ & $52.45 \pm 20.79$ & $61.78 \pm 18.86$ & $\mathrm{p}<0.01$ \\
実効值面積 $\left(\mathrm{cm}^{2}\right)$ & $81.65 \pm 36.99$ & $98.74 \pm 35.31$ & $\mathrm{p}<0.01$ \\
$\mathrm{X}$ 方向最大振幅 $(\mathrm{cm})$ & $17.77 \pm 3.95$ & $18.90 \pm 3.65$ & N.S. \\
$\mathrm{Y}$ 方向最大振幅 $(\mathrm{cm})$ & $12.32 \pm 2.70$ & $13.17 \pm 2.86$ & $\mathrm{p}<0.05$ \\
\hline
\end{tabular}

平均值士標準偏差, N.S. : not significant

統計処理として, ベルトなし姿勢とベルト有り姿勢 の 2 群に対して, 静的バランスでは総軌跡長, 単位軌跡 長, 矩形面積, 外周面積, 実効值面積, $\mathrm{X}$ 方向最大振 幅, $\mathrm{Y}$ 方向最大振幅を採用し, 動的バランスでは矩形 面積, 実効值面積, $\mathrm{X}$ 方向最大振幅, $\mathrm{Y}$ 方向最大振幅を Wilcoxon の符号付順位検定を用いて分析した。分析に はSPSS ver15.0を用い，有意水準 5\%とした。

\section{III. 結 果}

静的バランスでは総軌跡長, 矩形面積, 外周面積, 実効值面積, 単位軌跡長, $\mathrm{X}$ 方向最大振幅, $\mathrm{Y}$ 方向最大 振幅の開眼, 閉眼ともにベルトの有無で有意差が認め られなかった（表1）。

動的バランスではベルトなし姿勢よりもベルト有り 姿勢において矩形面積, 外周面積, 実効值面積, $\mathrm{Y}$ 方向 最大振幅でベルト有り姿勢のほうが有意に大きかった (表2)。

\section{IV. 考 察}

転倒と立位バランス機能は密接に関連しており，転 倒予防にはバランス能力の改善が一つの目標とされ, 臨 床において数々の理学療法アプローチが実施されてい る。従来までは下肢筋力強化 ${ }^{3)}$, 足底感覚の向上 ${ }^{4)}$ など のアプローチが主たる理学療法であったが, 瀬下ら ${ }^{5)}$ 腹部筋増強とバランス機能の改善に関する報告があり, 腹筋の強化とバランス機能の関係が明らかになりつつ ある。この報告では腹部の筋力増強によって, 適度な腹 腔内圧が確保され, それに伴って胸郭及び腹部の固定性 が高まり, 体幹の安定性が向上したことが示唆されてい る。そこで今回は十分に筋力増強の運動ができない高齢 者に適応するために, 腹部の圧力を簡易的に腹部ベルト で高めたときの静的・動的バランスの特性について調べ た。

腹部を簡易的な腹部ベルトで巻くことによって，腹

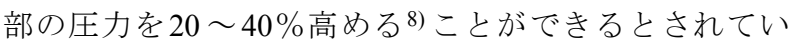


る。今回，ベルトの「有り」「なし」で静的・動的立位 バランスを計測した結果，静的バランスでは重心の移 動範囲に有意差は認められなかったが，動的バランス ではベルト有り姿勢で有意に矩形面積・外周面積・実 効值面積 ・ Y 方向最大振幅の項目が増加し, 重心の移 動範囲が拡大した。このことは, ベルトで腹部の圧力 を高めたことで腹部を中心として脊柱の固定性が高ま り, 腹筋群に適度な圧力を与えることができ, 姿勢制 御を要求した動的バランスが改善されたものと考えら れる。特に矩形面積や外周面積が拡大したことは, 前 後・左右方向への重心の制御能力の向上が考えられ, 腹 部ベルト使用による体幹・脊柱の安定性が腹筋群の強 化なしで得られた可能性が示唆された。

過去の研究では, ベルト使用時の筋活動においてス クワットの活動時9) や立位姿勢に乱刺激を加えた ${ }^{10)} と$ きに有意な減少が認められたとしている。このことは, ベルト装着により腹部筋の筋活動が補われたと考えら れる。また, McGill ら ${ }^{11)}$ は, ベルトの使用で体幹の屈 曲と伸展方向よりも側方と回旋方向で有意に体幹の固 定性が向上したと報告した。今回の動的バランスの結 果では, 左右方向で有意に重心の振幅が増加したこと は, ベルト装着で体幹の可動性が減少し, 過度な体幹 の動きを抑制されたことで，体幹の過剩な動きを制御 することなく重心の制御が可能になったことが示唆さ れた。腹部ベルトを使用することで腹部筋の活動を補 い, 下部体幹の固定性が向上し, 特に体幹が過度に可 動域の変化をすることなく, 側方方向での重心の制御 が向上したものと考えられる。

また，片麻痺患者の研究においてベルト装着により 重心の移動距離が変化せず, 側方リーチ距離が増大し たという報告 ${ }^{12)}$ がある。ベルトの装着によって下部体 幹, 腰部脊柱の安定性が向上したため, バランス機能 の指標の 1 つであるリーチの距離の向上がみられたも のと考えられる。本研究においてもべルト装着により 臨床上使用されている動的バランスの測定においても, 腹部ベルト使用の効果がみられた。このことからも， 今回使用した腹部ベルトが下部体幹の安定性を向上さ せ，高齢者のバランス機能の改善の一因に寄与しうる ものと示唆された。

本研究により, 腹部ベルトが腹部の安定性の向上に より立位バランス機能の向上に影響を与えていること が示唆された。しかし，長期にわたるコルセットの使 用は体幹筋の筋力を低下させる ${ }^{13)}$ 。そのため人工的な 腹圧の上昇だけではなく，瀬下ら ${ }^{5)}$ の報告のように腹 部の筋力強化や，諸家の報告通りに下肢筋力増強や足
底感覚の改善など身体機能へのアプローチを欠かして はいけないと考えている。だが，高齢者の転倒の一要 因を簡易的な腹部ベルトを利用して多少なりとも改善 する可能性が示された。今後は虚弱高齢者で同手法を 用いた検討をさらに腹部・下肢の筋活動を含めた総合 的な解析を追加して行うことや，腹部トレーニングの 効果の検討など, 腹部の安定性と転倒の関係性を明確 にしていきたいと考えている。

\section{引用文献}

1) 財団法人厚生統計協会 : 国民衛生の動向. 厚生の視標, 2006, 53(9): 220-232.

2) 萩原洋子, 網本 和, 牧田光代 - 他 : 大腿骨頸部骨折後の歩 行能力の推移と再転倒の現状. PTジャーナル, 1995, 29(11): 795-798.

3) 高倉 聡, 大城昌平, 中野裕之・他 : 高齢者用バランスボー ドN型と身体機能評価及び，転倒リスクとの関連．理学療法 科学, 2002, 29(2): 43-48.

4) 木藤伸宏, 井原秀俊, 三輪 恵 - 他 : 高齢者の転倒予防とし ての足指トレーニングの効果. 理学療法学, 2001, 28(7): 313319.

5) 瀬下寛之, 宇賀神直, 栗原律子・他 : 転倒予防としての腹筋 群強化の効果〜腹筋群強化がバランス機能に及ぼす影響〜。 理学療法群馬, 2004, 15: 42-45.

6) Urquhart DM, Hodges PW, Story IH: Postural activity of the abdominal muscle varies between regions of these muscles and between body positions. Gait Posture, 2005, 22(4): 295-301.

7) Urquhart DM, Barker PJ, Hodges PW, et al.: Regional morphology of the transverses abdominis and obliquus internus and externus abdominis muscle. Clinical Biomechanics, 2005, 20(3): 233241.

8) Lander JE, Hundley JR, Simonton RL: The effectiveness of weight-belts during multiple repetitions of the squat exercise. Med Sci Sports Exerc, 1992, 24(5): 603-609.

9) Warren LP, Appling S, Oladehin A, et al.: Effect of soft lumbar support belt on abdominal oblique muscle activity in nonimpaired adults during squat lifting. J Orthop Sports Phys Ther, 2001, 31(6): 316-323.

10) Cholewicki J, Juluru K, Radebold A, et al.: Lumbar spine stability can be augmented with an abdominal belt and/or increased intraabdominal pressure. Eur Spine J, 1999, 8: 388-398.

11) McGill S, Seguin J, Bennett G: Passive stiffness of the lumbar torso in flexion, extension, lateral bending, and axial rotation. Effect of belt wearing and breath holding. Spine, 1994, 19(6): 696-704.

12) 渡部雄樹, 桝谷真士, 佐々木誠: 片麻痺患者における坐位時 の圧中心軌跡 (COP) に対する腹部ベルト装着の影響. 理学 療法科学, 2004, 19(3): 131-135.

13) Eisinger DB, Kumar R, Woodrow R: Effect of lumbar orthotics on trunk muscle strength. Am J Phys Med Rehabil, 1996, 75(3): 194197. 